\title{
Effects of selenium-enriched Bacillus sp. compounds on growth performance, antioxidant status, and lipid parameters breast meat quality of Chinese Huainan partridge chicks in winter cold stress
}

\author{
Jiajun Yang ${ }^{1,2}$, Minhong Zhang ${ }^{1 *}$ and Ying Zhou ${ }^{1}$
}

\begin{abstract}
Background: Both selenium (Se) and probiotic Bacillus regulate the metabolism to help defense clod stress and improve the meat quality in breeding chicks. The purpose of this study was to evaluate the effect of supplemental Se and Bacillus in the form of Se-enriched Bacillus (SECB) on the growth performance, lipid parameters, breast Se and antibiotic levels, and breast meat quality of chicken in winter cold stress.

Methods: Five hundred 1-d-old chickens were divided into five groups randomly: Control, inorganic Se, compound Bacillus, SECB, and antibiotic. The feed duration was $56 \mathrm{~d}$.

Results: After 28 d of treatment, chicks feed SECB or compound Bacillus had higher body weights than the control, and after $56 \mathrm{~d}$, chicks given either SECB or compound Bacillus had higher body weights than the control chicks or those given inorganic Se. Adding SECB to feed significantly increased the lightness, redness, and yellowness of breast meat, improved the water-holding capacity, and reduced the shear force and cooking loss. The concentration of Se in the breast muscle very significantly increased after SECB and inorganic Se supplementation, which was opposite to the concentration of flavomycin in antibiotic supplemented chicks. The antioxidative status of plasma and breast meat was significantly improved with added compound Bacillus and SECB: the total antioxidant capacity, total superoxide dismutase, and glutathione peroxidase ability in the breast muscle significantly improved, and the malondialdehyde concentration in plasma decreased. The levels of total cholesterol plasma triglyceride and very-low-density lipoprotein cholesterol in the plasma and breast muscle was decreased compared to that of the control, while the plasma highdensity lipoprotein cholesterol concentration increased.
\end{abstract}

Conclusions: In conclusion, SECB supplementation promoted the body growth, antioxidative status, and Se concentrations in the plasma and breast meat, and also improved the breast meat quality.

Keywords: Selenium-enriched Bacillus, Chick, Growth performance, Breast meat, Stress

\footnotetext{
* Correspondence: yjj1984112@outlook.com

${ }^{1}$ State Key Laboratory of Animal Nutrition, Institute of Animal Sciences,

Chinese Academy of Agricultural Sciences, Yuanminyuan West Road, Haidian

District, Beijing 100094, China

Full list of author information is available at the end of the article
}

(c) The Author(s). 2019 Open Access This article is distributed under the terms of the Creative Commons Attribution 4.0 International License (http://creativecommons.org/licenses/by/4.0/), which permits unrestricted use, distribution, and reproduction in any medium, provided you give appropriate credit to the original author(s) and the source, provide a link to the Creative Commons license, and indicate if changes were made. The Creative Commons Public Domain Dedication waiver (http://creativecommons.org/publicdomain/zero/1.0/) applies to the data made available in this article, unless otherwise stated. 


\section{Background}

In the winter of most part of China, the outside temperature could be below $0{ }^{\circ} \mathrm{C}$. Usually, the temperature is below the suitable living standard for chick growth; it can lead to cold stress and diseases, causing bad meat quality and low breeding efficiency.

Selenium (Se) is an important trace element; its beneficial effects are well documented [1] which is relatively deficient in most areas of the world. Dietary Se deficiency is considered to be a causative factor of abnormal myocardial matrix remodeling and dysfunction in the normal heart [2]. Suitable doses of Se supplementation can regulate the metabolism of nutrient substances and improve digestion, stress, and antioxidation in animals [3-5]. Supplementation of the diet with tetravalent Se (IV) can be achieved using a salt of selenium, such as sodium selenite. Low-molecular-weight organic Se complexes, such as amino acids [6] and nano forms [7], provide a myriad of benefits; they have a higher organic bioavailability than the inorganic forms that are most often used as a dietary supplement [8]. However, their higher cost may inhibit widespread use. There are a number of stressors in industrial chick production, such as heat, cold, and group-transferred [9]. In order to defend against stress, other nutritional indigents would be assigned, which is not beneficial to body growth and meat quality. Considering the anti-stress role of $\mathrm{Se}$, it is of urgent need to explore a cheap and convenient organic Se source for supplementation.

Probiotics contain live microorganisms and spores which when administered in adequate amount, confer health benefts to the host [10]. Bacillus subtilis (B. subtilis) and Bacillus licheniformis (B. licheniformis) are the two most widely used strains of probiotic bacteria in animal diets [11, 12]. Oral administration of $B$. subtilis and $B$. licheniformis can have a myriad of beneficial effects, such as improved growth and meat characteristics [13-15], optimized composition of intestinal microbiota, prevention of some diarrheal diseases [16], and reduced stresses [17]. For such benefits, B. subtilis and B. licheniformis have attracted considerable attention as a potentially beneficial dietary supplement for animal health.

Considering the positive effects of Se and B. subtilis and $B$. licheniformis on growth performance, anti-oxidation, and stress $[17,18]$, it would be valuable to study whether the combined use of Se and compound Bacillus has greater effects on body growth and meat quality.

For the many negative effects of antibiotic drugs used in chick production, we want to compare the positive effects of two strains of compound Bacillus spp. and SECB to those of antibiotic drugs, which would be alternatively used in chick production. Chinese Huainan Partridge chicken is a dual-purpose native breed in South China. Because of the special habits of consuming, South
Chinese are interested in selecting the breed; hence the need for this study [19].

To test this hypothesis, we produced Se-enriched $B$. subtilis (SECB), which combines the virtues of B. subtilis and those of organic Se, and might induce an enhanced defense response against cold stress and improved meat quality through dietary supplementation.

\section{Methods}

\section{Chicks and management}

The animal treatment, housing, and husbandry conditions conformed to the experimental guidelines of the Institutional Animal Care and Use Committee of China. The experimental protocols in this study, including animal husbandry and slaughter, were approved by the Institution of Animal Science and Welfare of Anhui Province (no. IASWAP2017110649).

A total of 500 one-d-old Chinese Huainan Partridge chicken (average body weight, $40.15 \mathrm{~g}$ ) were randomly allocated into five groups with six replicates of 25 each. Chickens in the control group were fed a basal diet and the four treatments were fed the following: basal diet with either inorganic sodium selenite (IS), compound Bacillus (CB), selenium enriched compound Bacillus (SECB) and flavomycin. Experimental diets were fed in two periods: starter (days 0-28) and finisher (days 2956). The composition and nutrient analysis results for the basal diet, which did not contain any probiotics or antibiotics, are shown in Table 1 . All the nutrients met or exceeded the nutrient requirements (National Research Council, 2012) [20]. The chicks were net-reared from November 22 of 2017 to January 16 of 2018. For the duration of the starter diet, the pen space for each replicate was $2.3 \mathrm{~m}^{2}$. The room temperature was kept at $33-35^{\circ} \mathrm{C}$ by an electric heating tube in the first week, then gradually declined to $21^{\circ} \mathrm{C}$ at the end of the fourth week. At the end of the starter diet period, all chicks were weighted and transferred into larger pens $\left(5.6 \mathrm{~m}^{2}\right.$ for each replicate); chicks in the previous replicate were also transferred and kept under the same conditions. In the fifth week, the temperature was maintained at 18$21^{\circ} \mathrm{C}$ by infrared warming lights. In weeks six to eight, the number of infrared warming lights was reduced gradually for a room temperature of $8.5-15.5^{\circ} \mathrm{C}$. The chickens were allowed ad libitum access to water and feed throughout the experimental periods. The normal immune procedure was implemented throughout the whole trial.

\section{Feed for each group}

$B$. subtilis and B. licheniformis were isolated from the ileum of a healthy Chinese Huainan Partridge chicken by a group researching probiotic bacteria, the Institute of Animal Husbandry and Veterinary Medicine, Anhui 
Table 1 Composition and nutrient analysis of the basic diet for broilers at different stages

\begin{tabular}{llll}
\hline & Ingredient & Starter (0 28) \% & Finisher (29 56) \% \\
\hline Item & Corn & 57.97 & 61.75 \\
& Soybean meal & 29.45 \\
& Fish powder & 29.30 & 3.51 \\
& Soybean oil & 5.00 & 3.00 \\
& Premix & 2.00 & $5.00^{\mathrm{a}}$ \\
& Dicalcium phosphorus & $5.00^{\mathrm{a}}$ & 0.29 \\
Lalculated nutrient & Limestone & 0.47 & 0 \\
& Metabolizable energy (MJ / $/ \mathrm{kg})$ & 0.26 & 12.54 \\
& CP & 12.12 & 19 \\
& Calcium & 21 & 0.9 \\
& Total phosphorus & 1 & 0.65 \\
& Available phosphorus & 0.68 & 0.38 \\
& Lys & 0.45 & 0.9 \\
\hline
\end{tabular}

The premix provides

${ }^{a}$ vitamins and trace elements per kg diet: Vitamin A (retinyl acetate) 9, $875 \mathrm{IU}$, Vitamin $\mathrm{D}_{3}$ (cholecalciferol) 3, $000 \mathrm{IU}$, Vitamin E (DL-a-tocopheryl acetate) $20 \mathrm{IU}$, menadione $3.25 \mathrm{mg}$, Vitamin $B_{12}$ (cyanocobalamin) $0.025 \mathrm{mg}$, thiamin $1.5 \mathrm{mg}$, riboflavin $5.0 \mathrm{mg}$, biotin $0.032 \mathrm{mg}$, folacin $1.25 \mathrm{mg}$, niacin $12 \mathrm{mg}$, pantothenic acid $12 \mathrm{mg}$, and pyridoxine $3.75 \mathrm{mg}$, manganese $100 \mathrm{mg}$, zinc $80 \mathrm{mg}$, iron $80 \mathrm{mg}$, copper $8 \mathrm{mg}$, iodine $0.15 \mathrm{mg}$, and selenium $0.15 \mathrm{mg}$

Academy of Agricultural Sciences, which were stored in the China General Microbiological Culture Collection Center. We cultured B. subtilis and B. licheniformis with a liquid beef extract-peptone medium. The number of live Bacillus reached $6.6 \times 10^{8} \mathrm{CFU} / \mathrm{mL}$, respectively, after fermentation. The fermentation of selenium-enriched B. subtilis and $B$. licheniformis was prepared with sodium selenite supplemented into the culture medium until the Se concentration reached $50 \mu \mathrm{g} / \mathrm{mL}$. After fermentation, SECB were harvested, the organic Se reached $48.13 \mu \mathrm{g} / \mathrm{mL}$ mainly as Se protein (contained 93.17\%), and live numbers of B. subtilis and $B$. licheniformis were $3.3 \times 10^{7}$ and $6.6 \times 10^{7} \mathrm{CFU} / \mathrm{mL}$ respectively. For the chick in the IS group, $1.12 \mathrm{~g}$ of sodium selenite (analytically pure) was diluted into $100 \mathrm{~mL}$ of distilled water, which was blended with $5 \mathrm{~kg}$ of feed. Then, the mixed mass feed was added into a blender contained $90 \mathrm{~kg}$ of mass feed. The blender was employed for $20 \mathrm{~min}$ to mix the additives uniformly. The feed for the flavomycin group was prepared using $4 \mathrm{~g}$ of premixed food containing $10 \%$ flavomycin, which was blended with $100 \mathrm{~kg}$ of feed, to reach a concentration of $4 \mathrm{mg} / \mathrm{kg}$. For compound Bacillus, $50 \mathrm{~mL}$ of B. subtilis and $100 \mathrm{~mL}$ of B. licheniformis fermentation liquid were measured separately and first blended with $5 \mathrm{~kg}$ of feed, and then with $95 \mathrm{~kg}$ of mass feed after. The SECB feed was prepared by blending $1000 \mathrm{~mL}$ of SECB fermentation liquid with $100 \mathrm{~kg}$ of feed. After preparing the five different feedstuffs, the population of B. subtilis and $B$. licheniformis were counted using the plate method with a yeast extract peptone dextrose medium. The concentration of Se in all feed types was also measured. The results were listed in Table 2.

\section{Performance and sample collection}

Chicks in every replicate of each treatment group were weighed on $0 \mathrm{~d}, 28 \mathrm{~d}$, and $56 \mathrm{~d}$. Daily feed consumption was accurately recorded. Daily weight gain and ratio of feed to gain (F:G) were calculated. ADG = body increase $(\mathrm{g}) /$ number of days. F:G ratio = mass of food intake $(\mathrm{g}) /$ body increase $(\mathrm{g})$.

After $56 \mathrm{~d}$, two chickens from each replicate were selected, fasted for $12 \mathrm{~h}$, and then the tissue and blood were harvested under general halothane anesthesia. All blood samples were collected in $5.0 \mathrm{~mL}$ sterile heparinized tubes. We removed $1 \mathrm{~mL}$ of each blood sample to measure the Se concentration. Then, remnant chick blood was centrifuged at $3000 \mathrm{rpm} / \mathrm{min}$ for $10 \mathrm{~min}$ to collect the plasma for biochemical assays (described below). Breast meat was collected and stored at $4{ }^{\circ} \mathrm{C}$ until analysis.

\section{The assay of antioxidation}

The blood of chickens was harvested from the wing vein and precipitated at $3000 \times \mathrm{g}$ for $10 \mathrm{~min}$ to obtain the plasma. Then, $0.3 \mathrm{~g}$ of breast muscle samples in each group was weighed to prepare the homogenate. Plasma and breast muscle malondialdehyde, anti-oxidative enzymes (superoxide dismutase, glutathione peroxidase), and total antioxidant capacity were detected using kits. Six replicates were used in each experiment.

\section{Lipid parameters analyses}

Concentration of total cholesterol in the plasma and breast muscle, plasma triglyceride and very low- and 
Table 2 Concentration of Se and number of B. suthilis in Groups

\begin{tabular}{lll}
\hline Groups & Concentration of Se $(\mathrm{ng} / \mathrm{g})$ & number of B. suthilis:B.licheniformis (CFU/g) \\
\hline Control & 102.0 & 0 \\
IS & 602.0 & 0 \\
CB & 102.0 & $3.3 \times 10^{5}: 6.6 \times 10^{5}$ \\
SECB & 602.0 & $3.3 \times 10^{5}: 6.6 \times 10^{5}$ \\
Flavomycin & 102 & 0 \\
\hline
\end{tabular}

high-density lipoprotein cholesterol concentrations were measured using the appropriate detection kits (Nanjing Jiancheng Bioengineering Institute).

\section{Breast meat quality analysis}

Breast muscle samples were collected for meat quality at the end of the experiment. After being maintained at $4^{\circ}$ $\mathrm{C}$ for $24 \mathrm{~h}$, the meat redness $\left(\mathrm{a}^{*}\right)$, yellowness $\left(\mathrm{b}^{*}\right)$, and lightness $\left(\mathrm{L}^{*}\right)$ was determined by a Chroma meter (CR-410; Minolta Co., Tokyo, Japan). Water-holding capacity (WHC) was measured by determining expressible juice using a modification of the filter paper press method indicated by Wierbicki and Deatherage, as follows [21]. The breast meat was refrigerated overnight at $4{ }^{\circ} \mathrm{C}$ and then brought to room temperature before cooking to measure the cooking loss and shear force. The breast muscle from each bird was placed into a thin walled plastic bag and cooked to an internal temperature of $70{ }^{\circ} \mathrm{C}$ in a water bath with a digital thermostat. The cooked muscle was cooled to room temperature. The Warner-Bratzler shear force was determined using an Instron Universal Mechanical Machine (Instron Model 4411; Instron Corp., Canton, MA). Each sample was then cooled under tap water and equilibrated at room temperature. The muscle was weighed again for determination of cooking loss (\%). Shear force was inspected by cutting eight $1 \times 1 \mathrm{~cm}$ cores of about $3 \mathrm{~cm}$ thick, harvested parallel to the fiber orientation, through the thickest portion of the cooked muscle.

\section{The assay of se concentration}

A ZEEnit $700 \mathrm{P}$ atomic absorption spectrometer (Analytik Jena, Germany) was employed to determine the selenium levels in the breast meat and plasma. All measurements were performed using the described method [22]. First, $0.3 \mathrm{~g}$ samples of breast meat and 1.0 $\mathrm{mL}$ of plasma from all groups were placed in beakers and digested by adding $10 \mathrm{ml}$ of a nitric acid-perchloric acid ( $\mathrm{HNO} 3-\mathrm{HClO} 4)$ mixture. The mixture was heated on a sand bath until fumes appeared (the temperature was maintained at $200{ }^{\circ} \mathrm{C}$ ) and the solution had mostly evaporated. After cooling, $5 \mathrm{~mL}$ of hydrochloric acid solution $(6 \mathrm{~mol} / \mathrm{L})$ was added, and the heating procedure was repeated at $180{ }^{\circ} \mathrm{C}$. The cooled mixture was made up to $10 \mathrm{~mL}$ with $5 \%$ hydrochloric acid solution. Eight replicates were used for each group.

\section{Flavomycin assay}

Samples of $0.3 \mathrm{~g}$ of breast meat were weighed and placed in $5 \mathrm{~mL}$ plastic tubes. Then, $3.6 \mathrm{~mL}$ of ammonium methanol (ammonia:methanol $[\mathrm{v}: \mathrm{v}]=9: 1$ ) were added to homogenize. The homogenous liquid was centrifuged at $12,000 \times \mathrm{g}$ for $3 \mathrm{~min}$ at $4{ }^{\circ} \mathrm{C}$. After, $0.5 \mathrm{~mL}$ of supernatant was removed into a sterilized plastic tube and $2 \mathrm{~mL}$ acetonitrile was added, which were precipitated at $12000 \times \mathrm{g}$ for $10 \mathrm{~min}$ at $4{ }^{\circ} \mathrm{C}$. The supernatant was removed into another sterilized plastic tube, and dried using a stream of nitrogen. The samples were made up to a volume of $1 \mathrm{~mL}$ using methanol, and filtered using $0.22-\mu \mathrm{m}$ filter membrane. The concentration of flavomycin was measured with liquid chromatography-tandem mass spectrometry (LC-MS/MS) following the methods of the reported reference [23].

\section{Statistical analyses}

Body weight, meat quality, Se and flavomycin concentration, and antioxidation data were subjected to one-way ANOVA using the GLM procedure of SPSS, with significance reported at $P<0.05$. Means were further separated using Duncan's multiple range test. Data on body weight, average daily gain, average daily feed intake, and F:G ratio were statistically processed as repeated measures. A $P$-value of less than 0.05 was considered statistically significant.

\section{Results}

\section{Growth performance}

The growth performance of Chinese Huainan Partridge chickens in five groups is shown in Figs. 1, 2 and 3. At 28 $\mathrm{d}$, chickens in groups supplemented with $\mathrm{CB}, \mathrm{SECB}$, and flavomycin had higher final body weights than those in the control or IS groups $(P<0.05)$. The ADG indices of the control and IS groups were not significant $(P>0.05)$ at $28 \mathrm{~d}$, and were significantly lower than those of the $\mathrm{CB}$, SECB, and flavomycin supplemented groups $(P<0.05)$. However, the result of the F:G ratio was opposite to that of the final body weight. Birds that received $C B, S E C B$, and flavomycin had lower F:G ratios $(P<0.05)$. There were no differences in the ADFI among the four groups either after 28 or $56 \mathrm{~d}(P>0.05)$. 


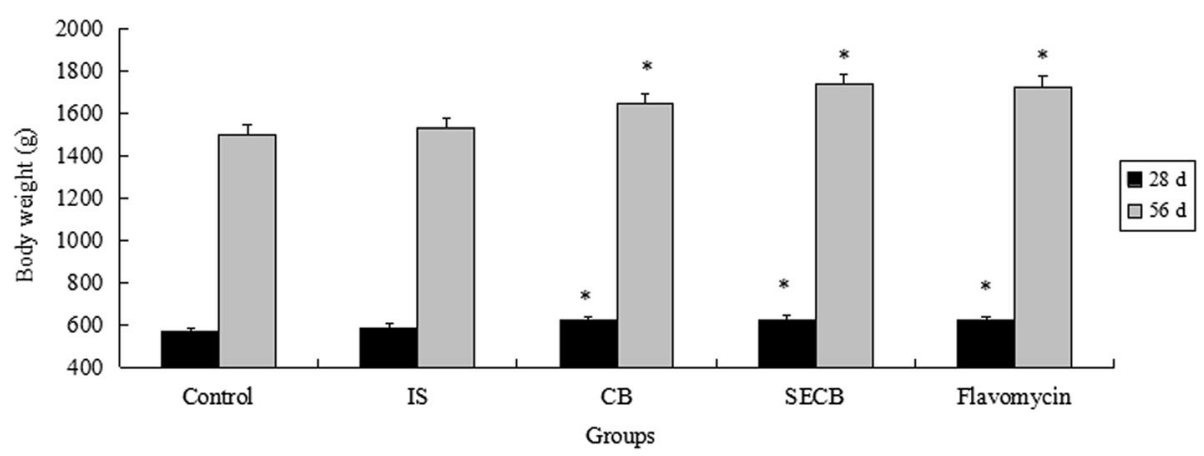

Fig. 1 Effects of different treatments on chicken body weight. The chicken were treated with control, inorganic Se (IS), compound Bacillus (CB), selenium enriched compound Bacillus (SECB) and antibiotic (flacomycin) after 28 and 56 days. Bars represent mean \pm S.E. Bar in same color with with $^{\prime \prime \prime \prime}$ is significantly different from those without $(P<0.05)$

After $56 \mathrm{~d}$, the final body weights in the CB, SECB and flavomycin groups were still significantly higher compared to those of the control (about $235 \mathrm{~g}$ ) and inorganic Se-supplemented groups $(P<0.05)$. The ADG indices of the $\mathrm{CB}, \mathrm{SECB}$ and flavomycin groups were significantly higher than those of the control and IS groups $(P<0.01)$. There were no differences in ADG between the $\mathrm{CB}$ and flavomycin or flavomycin and SECB groups $(P>0.05)$. Over the entire feeding duration, the F:G ratio in the SECB group was the lowest $(P<0.05)$. The F:G ratio of SECB was the lowest among all groups $(P<0.01)$, but had no significant difference to that of the flavomycin group $(P>0.05)$. The indices of chicks in the $\mathrm{CB}$ and flavomycin supplemented groups declined very significantly compared to those of chicks in the control and IS groups $(P<0.01)$.

\section{Antioxidative levels of plasma and breast meat}

After $56 \mathrm{~d}$, the antioxidation capacity of plasma and breast meat was analyzed (Table 3). The concentrations of MDA in the plasma of all supplemented groups declined significantly compared to that of the control. The MDA content in the SECB group was the lowest, at $3.21 \mu \mathrm{mol} / \mathrm{L}$ lower than that of the control $(P<0.05)$.
The MDA concentration of breast muscle in all supplementary groups was lower than that of the control $(P<0.05)$, and that of SECB was the lowest of all groups $(P<0.05)$. There were no differences among the other supplemented groups $(P>0.05)$. The superoxide dismutase (SOD) activity results were in reverse to the concentration of MDA results. The SOD activity was increased in both the plasma and breast muscle in all supplementary groups $(P<0.05)$, while the index in SECB was the highest among all five groups $(P<0.05)$. No significant differences were found among the IS, $\mathrm{CB}$, and flavomycin groups $(P>0.05)$. The activities of glutathione peroxidase (GPx) in the two groups with Se supplementation were significantly higher than those in all other groups $(P<0.05)$ both in plasma and breast muscle. The activity of GPx in plasma with added SECB was higher than that of the control, with approximately 44.79 and 27.58 units in the plasma and breast muscle, respectively. There were no differences among the groups without Se supplementation $(P>0.05)$. The total antioxidant capacity (T-AOC) index in the control was lower than those in other treatments, both in the plasma and breast muscle $(P<0.05)$. There were no differences in the T-AOC of

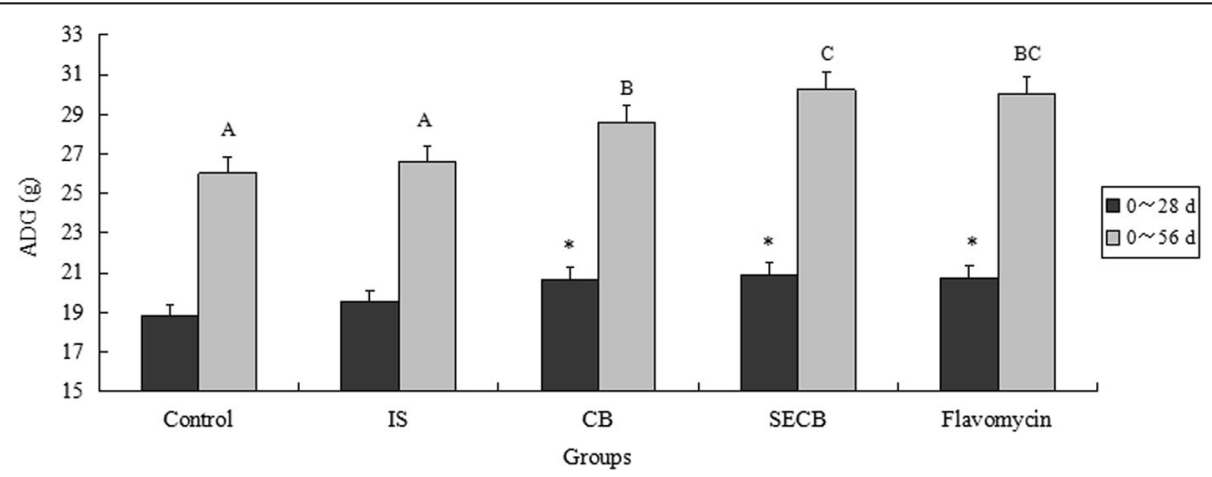

Fig. 2 Effects of different treatments on chicken average daily gain. The chicken were treated with control, IS, CB, SECB and flacomycin after 28 and 56 days. Bars represent mean \pm S.E. Bar in same color with with A, B mean significant difference at 0.01 levels $(P<0.01)$ 


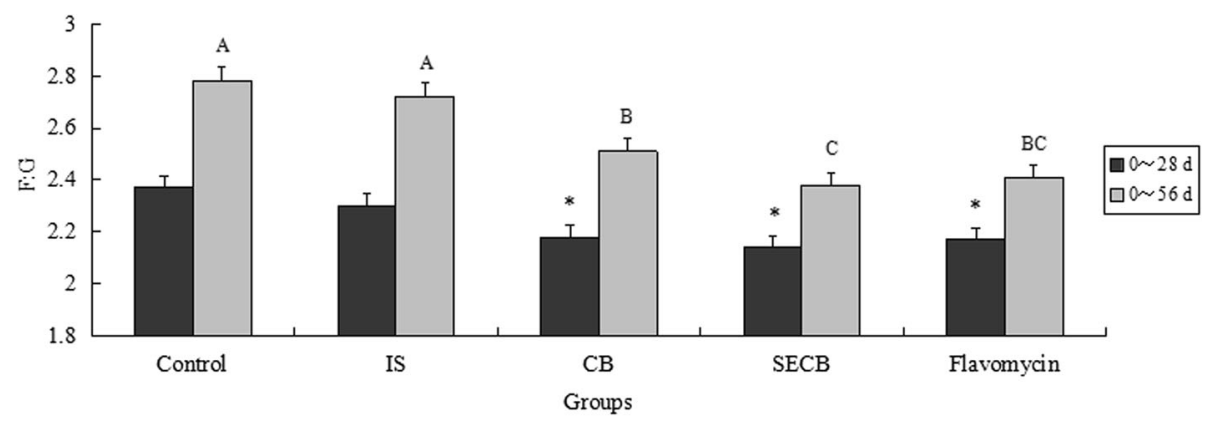

Fig. 3 Effects of different treatments on chicken ratio of feed to gain. The chicken were treated with control, IS, CB, SECB and flacomycin after 28 and 56 days. Bars represent mean \pm S.E. Bar in same color with A, B, C mean significant difference at 0.01 levels $(P<0.01)$

plasma among all groups $(P>0.05)$. In the breast muscle, the T-AOC result of the SECB group was higher than that of the IS and flavomycin groups $(P<0.05)$, and no difference was found in the CB group $(P>0.05)$.

\section{Lipid parameters analyses}

The levels of (Table 4) total cholesterol, triglyceride, and very low- and high-density lipoprotein cholesterol in the SECB group were significantly lower than those in the control $(P<0.05)$, but were not significantly different to those in the $\mathrm{CB}$ group $(P>0.05)$. The amounts of HDL in the plasma in the SECB and CB groups were higher than that in the control group $(P<0.05)$. The concentration of total cholesterol (Fig. 4) in the SECB group was $0.75 \mathrm{mmol} / \mathrm{L}$ lower than that of the control group $(P<$

Table 3 Effects of different treatments on antioxidation of plasma and breast muscle

\begin{tabular}{|c|c|c|c|c|}
\hline Groups & $\begin{array}{l}\mathrm{MDA} \\
\mu \mathrm{mol} \cdot \mathrm{L}^{-1}\end{array}$ & $\begin{array}{l}\mathrm{SOD} \\
\mathrm{U} / \mathrm{mL}\end{array}$ & $\begin{array}{l}\mathrm{GPX} \\
\mathrm{mol} / \mathrm{L}\end{array}$ & $\begin{array}{l}\text { T-AOC } \\
\text { Unit / mL serum }\end{array}$ \\
\hline & \multicolumn{4}{|l|}{ Plasma } \\
\hline Control & $8.47^{\mathrm{a}}$ & $101.05^{\mathrm{a}}$ & $318.45^{\mathrm{a}}$ & $13.96^{\mathrm{a}}$ \\
\hline IS & $7.53^{b}$ & $111.24^{\mathrm{b}}$ & $359.37^{b}$ & $14.83^{b}$ \\
\hline $\mathrm{CB}$ & $6.49^{c}$ & $115.36^{\mathrm{b}}$ & $319.51^{\mathrm{a}}$ & $14.98^{\mathrm{b}}$ \\
\hline SECB & $5.25^{\mathrm{d}}$ & $130.45^{c}$ & $363.24^{b}$ & $15.25^{b}$ \\
\hline Flavomycin & $6.53^{c}$ & $110.15^{\mathrm{b}}$ & $312.33^{\mathrm{a}}$ & $14.97^{b}$ \\
\hline SEM & 0.06 & 1.25 & 3.94 & 0.11 \\
\hline \multirow[t]{2}{*}{$P$-value } & 0.14 & 0.15 & 0.16 & 0.18 \\
\hline & \multicolumn{4}{|c|}{ Breast muscle } \\
\hline Control & $10.02^{a}$ & $83.22^{a}$ & $192.31^{\mathrm{a}}$ & $11.56^{\mathrm{a}}$ \\
\hline IS & $8.89^{b}$ & $96.51^{b}$ & $220.26^{b}$ & $12.63^{b}$ \\
\hline$C B$ & $7.92^{\mathrm{b}}$ & $101.92^{\mathrm{b}}$ & $195.52^{\mathrm{a}}$ & $13.18^{b c}$ \\
\hline SECB & $6.05^{c}$ & $110.39^{c}$ & $219.89^{b}$ & $13.45^{\mathrm{c}}$ \\
\hline Flavomycin & $8.54^{\mathrm{b}}$ & $102.61^{b}$ & $188.98^{\mathrm{a}}$ & $12.67^{b}$ \\
\hline SEM & 0.07 & 1.19 & 2.01 & 0.09 \\
\hline$P$-value & 0.09 & 0.07 & 0.10 & 0.11 \\
\hline
\end{tabular}

The different superscript small letters in the same column a,b mean significant difference at 0.05 levels $(P<0.05)$
0.05), which showed difference to that of the $\mathrm{CB}$ group $(P>0.05)$.

\section{Breast meat quality}

The breast meat color $\left(\mathrm{L}^{*}, \mathrm{a}^{*}\right.$, and $\left.\mathrm{b}^{*}\right)$, water-holding capacity, shear force, and cooking loss were measured on 56-d-old chicks, and the results are shown in Table 5. Chicks in the two $\mathrm{CB}$ supplemented groups had lower $\mathrm{L}^{*}$ and $\mathrm{b}^{*}$, and higher $\mathrm{a}^{*}$ values $(P<0.05)$ than chickens in the control, IS, and flavomycin groups $(P<0.05)$. The $\mathrm{L}^{*}, \mathrm{a}^{*}$, and $\mathrm{b}^{*}$ indices of chicks supplemented with CEBS were optimal in all treatments $(P<0.05)$. Birds supplemented with SECB and CB had higher water-holding capacities and lower cooking losses than those of the control group $(P<0.05)$. In addition, the index of cooking loss in the SECB group was the lowest of all the groups $(P<0.05)$. The results of shear force in the four treatments were lower than that of the control $(P<$ $0.05)$, while the result of the SECB group was the lowest of all the groups $(P<0.05)$.

\section{Levels of selenium and flavomycin}

The Se levels in the plasma and breast meat were measured, with the results shown in Fig. 5. The results indicated that the IS group had significantly more Se in the

Table 4 Effects of different treatments on lipid parameters of plasma

\begin{tabular}{|c|c|c|c|c|}
\hline Groups & $\mathrm{TC} \mathrm{mmol} / \mathrm{L}$ & $\mathrm{TG} \mathrm{mmol} / \mathrm{L}$ & LDLC mmol/L & $\mathrm{HDLC} \mathrm{mmol} / \mathrm{L}$ \\
\hline & Plasma & & & \\
\hline Control & $3.61^{\mathrm{a}}$ & $1.05^{\mathrm{a}}$ & $1.51^{\mathrm{a}}$ & $0.71^{\mathrm{a}}$ \\
\hline IS & $3.63^{\mathrm{a}}$ & $1.04^{\mathrm{a}}$ & $1.48^{\mathrm{a}}$ & $0.73^{\mathrm{a}}$ \\
\hline$C B$ & $3.19^{\mathrm{b}}$ & $0.91^{b}$ & $1.28^{\mathrm{b}}$ & $0.83^{b}$ \\
\hline SECB & $3.11^{\mathrm{b}}$ & $0.88^{b}$ & $1.24^{\mathrm{b}}$ & $0.85^{b}$ \\
\hline Flavomycin & $3.58^{\mathrm{a}}$ & $1.06^{\mathrm{a}}$ & $1.53^{\mathrm{a}}$ & $0.75^{\mathrm{a}}$ \\
\hline SEM & 0.08 & 0.03 & 0.05 & 0.02 \\
\hline$P$-value & 0.14 & 0.11 & 0.16 & 0.09 \\
\hline
\end{tabular}

The different superscript small letters in the same column a,b mean significant difference at 0.05 levels $(P<0.05)$ 


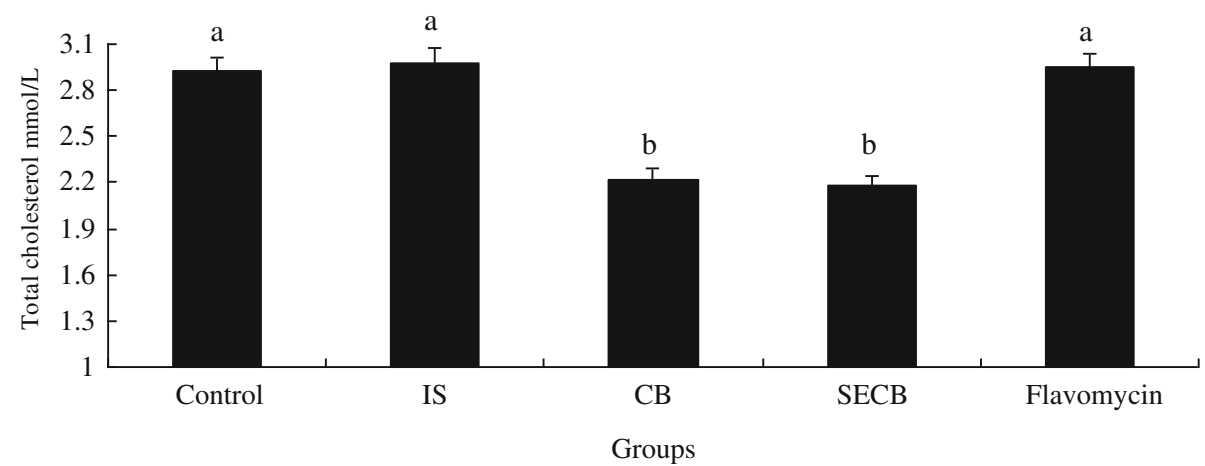

Fig. 4 Effects of different treatments on total cholesterol of breast muscle. The chicken were treated with control, IS, CB, SECB and flacomycin after 28 and 56 days. Bars represent mean \pm S.E. Bar in same color with $a, b$ is significantly different from those without $(P<0.05)$

plasma and breast meat than the control and CB supplementation groups $(P<0.01)$. Chickens in the SECB group had the highest Se levels in both tissues $(P<0.01)$.

The flavomycin concentration of breast muscle in supplemented groups reached $76.13 \mathrm{ng} / \mathrm{g}$ meat, while there were no detected results in non-supplemented groups.

\section{Discussion}

The merits of Se and probiotic bacteria on body were well-documented [19, 24]. B. licheniformis and B. subtilis, two strains of probiotic Bacillus, have a better ability to live in adverse environments (low-moisture, high pelleting temperature, and less nutrients) than Lactobacillus, [25], which were more widely developed as additives in the biomedical industry. SECB owing the organic Se and compound Bacillus (B. licheniformis and B. subtilis) would combine the beneficial effects of the two factors on growth performance of chick. In this research, the results indicated that with CB and SECB supplementation, chicks have higher body weights when transferred at $28 \mathrm{~d}$. While there were no significant effects of IS supplementation. The promoting effect on growth was also shown in the final body weight (56 d) of the CB, SECB, and flavomycin

Table 5 Effects of different treatments on chicken breast meat characteristics

\begin{tabular}{|c|c|c|c|c|c|c|}
\hline \multirow[t]{2}{*}{ Groups } & \multicolumn{3}{|c|}{ Meat color } & \multirow{2}{*}{$\begin{array}{l}\text { WHC } \\
(\%)\end{array}$} & \multirow{2}{*}{$\begin{array}{l}\text { Shear } \\
\text { force } \\
(\mathrm{kg} / \\
\left.\mathrm{mm}^{2}\right)\end{array}$} & \multirow{2}{*}{$\begin{array}{l}\text { Cooking } \\
\text { loss (\%) }\end{array}$} \\
\hline & $\mathrm{L}^{*}$ & $a^{*}$ & $b^{*}$ & & & \\
\hline Control & $51.18^{a}$ & $12.71^{a}$ & $16.02^{a}$ & $66.47^{a}$ & $2.81^{a}$ & $16.95^{a}$ \\
\hline IS & $52.36^{\mathrm{a}}$ & $12.93^{\mathrm{a}}$ & $16.84^{\mathrm{a}}$ & $67.91^{\mathrm{a}}$ & $2.76^{\mathrm{a}}$ & $15.99^{\mathrm{ab}}$ \\
\hline $\mathrm{CB}$ & $49.19^{b}$ & $13.21^{b}$ & $15.22^{b}$ & $72.17^{b}$ & $2.23^{b}$ & $14.81^{b}$ \\
\hline SECB & $46.02^{c}$ & $15.38^{c}$ & $14.08^{c}$ & $72.98^{c}$ & $1.90^{c}$ & $13.11^{c}$ \\
\hline Flavomycin & $51.27^{\mathrm{a}}$ & $12.36^{\mathrm{a}}$ & $16.11^{\mathrm{a}}$ & $66.79^{a}$ & $2.79^{a}$ & $16.45^{\mathrm{a}}$ \\
\hline SEM & 0.45 & 0.14 & 0.16 & 0.48 & 0.03 & 0.10 \\
\hline P-value & 0.031 & 0.026 & 0.021 & 0.019 & 0.028 & 0.034 \\
\hline
\end{tabular}

The different superscript small letters in the same column a,b mean significant difference at 0.05 levels $(P<0.05)$ groups. Both Se and B. subtilis have the ability to modulate the growth performance of chickens [18, 26, 27]. In our study, we supplemented basal feedstuff with a dose of $0.5 \mu \mathrm{g} / \mathrm{g}$ Se in an inorganic form, which had no positive effects on Chinese Huainan Partridge chicken; this is in accordance with existing studies [28, 29]. The results indicated that growth rates were improved in chickens given CB or SECB supplements. The microbial metabolites include antimicrobial substances like iturin and surfactin produced by $B$. subtilis, and enzyme protease, lipase, and amylase produced by $B$. licheniformis, which play an important role in keeping the body healthy and breaking down feed for nutrient absorption [30]. Chickens supplemented with SECB had (on average) higher body weights and greater feed utilization efficiencies than did the control group chickens. The F:G ratio of the SECB group was the lowest over the entire feeding period, suggesting that this treatment was more efficient than $\mathrm{CB}$ alone in regulating body growth performance.

Selenium is the cofactor of many kinds of proteins and enzymes, such as selenoprotein P and GPx $[1,8]$. The enzyme of GPx is required for the protection of the body against oxidative damage from hydrogen peroxide and other lipid hydroperoxides and derivatives [31, 32]. There are four kinds of GPx in the body. Types 1 and 2 of GPx were cytoplasm and plasma [33]. The basal diet contained Se at $0.095-0.128 \mu \mathrm{g} / \mathrm{g}$ of total solids, which satisfied the nutritional needs of the chick $(0.100 \mathrm{mg} \mathrm{Se} /$ $\mathrm{kg}$ of feed dry matter) as set by the National Research Council [20]. Adequate Se is essential for the protection of the immune system from oxidative damage [34]. Dietary Se supplementation holds promise as a means of treating inflammatory conditions, rejuvenating the aging immune system, and protecting the organism from pathogens $[8,35]$. When the concentration of Se reaches $0.5 \mu \mathrm{g} / \mathrm{g}[36,37]$, the activity of plasma GPx (GPx1) is higher than those of groups without supplementation. The activity of GPx2 in the breast muscle with Se supplementation was also significantly increased. Chick 


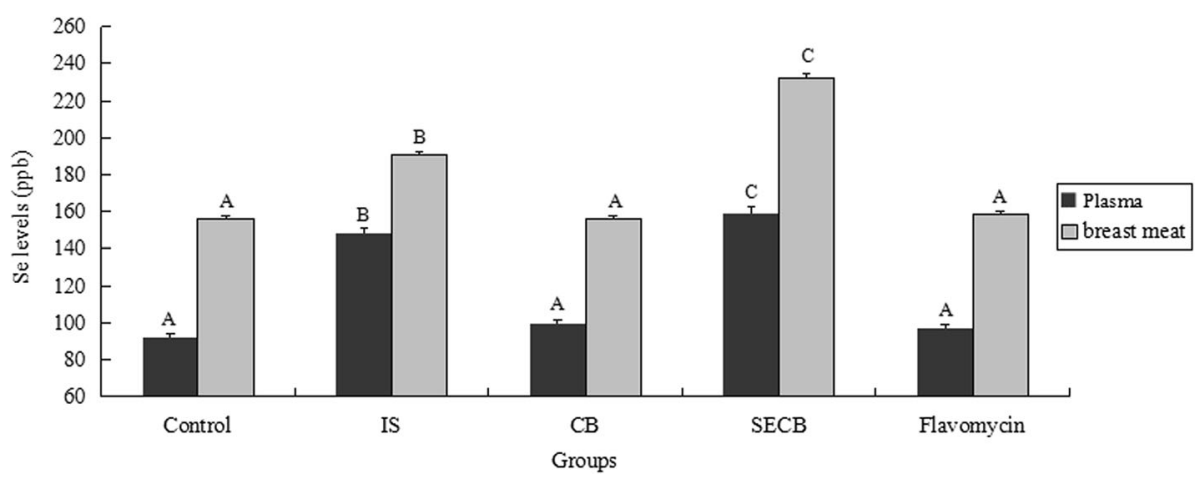

Fig. 5 Effects of different treatments on selenium levels of plasma and breast meat. The chicken were treated with control, IS, CB, SECB and flacomycin after 28 and 56 days. Bars represent mean \pm S.E.Bar in same color with different small letters $A, B, C$ mean significant difference at 0.01 levels $(P<0.01)$

supplemented with SEBC had even higher activities of GPx1 and GPx2. Results of other indices of antioxidation, such as the concentration of MDA and activities of SOD and T-AOC, were all improved in the plasma and breast meat with $0.5 \mu \mathrm{g} / \mathrm{g}$ Se and CB supplementation. The antioxidative effect of SECB was optimized for Chinese Huainan Partridge chicks in winter, which are subjected to cold and transport stressors.

Our data indicated that the concentrations of plasma total cholesterol and triglycerides were decreased in chicks treated with compound Bacillus and SECB, and did not change in IS- and flavomycin-supplemented chicks. Bacillus regulates the metabolism of body lipids [38]. HDLC, mainly synthesized in the liver and the small intestine, plays an important part in eliminating serum cholesterol. We found that supplemental IS and flavomycin play no role in reducing the plasma LDLC levels and increasing HDLC levels, which suggested little effect on lipid metabolism. However, the effect of SECB was obvious. Herein, the main effector was $\mathrm{CB}$, which is in accordance with previous results [38].

When probiotics are used to enhance the meat quality, their effects have been queried, and many opposite results have been reported. Some studies have reported advantages of probiotic supplementation [13, 39, 40], whereas others reported no beneficial effects [24]. L* and $b^{*}$ values correlated positively with drip loss and cooking loss. The reason for the reduced $L^{*}$ and $b^{*}$ values might be associated with the elevated antioxidant activities of $\mathrm{CB}$ and $\mathrm{SECB}$, which could protect cells from damage, prevent cell sap extravasation, and reduce the light reflection. Poultry meat is easily attacked by free radicals and oxidized because of a high concentration of polyunsaturated fatty acids [41]. Therefore, the antioxidant condition of the muscles influences the meat quality. Our result indicated that no differences were observed in the $\mathrm{L}^{*}, \mathrm{a}^{*}$, and $\mathrm{b}^{*}$ values in the IS and flavomycin group compared to those in the control group.
However, the $L^{*}$, $a^{*}$, and $b^{*}$ values improved in the $C B$ and SECB groups; the effect of SECB was stronger than that of $\mathrm{CB}$. The water-holding capacities, comprising cooking loss and shear force, are also crucial indices of meat quality, because some nutrients are easily lost during exudation by water loss [42]. Shear force is often expressed as the capacity for tenderness, and is one of the crucial sensory qualities that influences the consumer [43]. According to Maltin, tenderness is the most important factor that affects meat acceptance [44]. Our results suggested that water-holding capacity, shear force, and cooking loss were improved with $\mathrm{CB}$ and SECB supplementation. However, no effects were observed in the IS and flavomycin groups compared to the control group. The dietary addition of SECB combined the positive effects of Se and B. subtilis, and could have strong regulating roles in antioxidation and metabolism in improving meat color.

Previous studies have reported that Se supplementation can increase the Se content of tissues, although the results varied [45]. In our study, the Se contents in the breast meat and blood were very significantly increased in the IS and SECB groups, which indicated that the supplemental Se in SECB had a significant influence on the Se content of breast muscle; this is in accordance with previous reports $[29,37]$. The effect of SECB was greater than that of IS in this experiment, suggesting that SECB had greater availability as an Se resource. However, antibiotic supplementation negatively affected the breast meat flavomycin concentration, suggesting that antibiotics should be used judiciously despite its role in infectious disease prevention.

\section{Conclusions}

In conclusion, dietary SECB supplementation improved the growth performance and breast meat quality for the rearing of healthier Chinese Huainan Partridge chicks in cold environments, and could be used as a substitution to antibiotic drugs. 


\section{Abbreviations}

$a^{*}$ : Redness; ADG: Average daily weight gain; $b^{*}$ : Yellowness; F/G: Ratio of feed to gain; L*: Lightness; Se: Selenium; SECB: Selenium enriched compound bacillus; WHC: Water-holding capacity

\section{Acknowledgements}

Not applicable

\section{Funding}

The work was supported by the fund of State Key Laboratory of Animal Nutrition (No:: 2004D125184f1703), the Key National Research and Development Program project of China (No.: 2016YFD0500509), Natural Science Foundation of Anhui province (No.: 1708085QC72).

\section{Availability of data and materials}

The datasets supporting the conclusions of this article are included within the article.

\section{Authors' contributions}

JJY carried out the animal experiments and data analysis, and drafted the manuscript. $Y Z$ took part in samples collection. $\mathrm{MHZ}$ revised the manuscript. All authors read and approved the final manuscript.

\section{Ethics approval and consent to participate}

The experimental protocols in this study including animal husbandry and slaughter were approved by the Institution of Animal Science and Welfare of Anhui Province (no. IASWAP2017110649).

\section{Consent for publication}

Not applicable

\section{Competing interests}

The authors declare that they have no competing interests.

\section{Publisher's Note}

Springer Nature remains neutral with regard to jurisdictional claims in published maps and institutional affiliations.

\section{Author details}

${ }^{1}$ State Key Laboratory of Animal Nutrition, Institute of Animal Sciences, Chinese Academy of Agricultural Sciences, Yuanminyuan West Road, Haidian District, Beijing 100094, China. ${ }^{2}$ Anhui Province Key Laboratory of Livestock and Poultry Product Safety Engineering, Institute of Animal Husbandry and Veterinary Medicine, Anhui Academy of Agriculture Science, NongKe South of Road, Hefei 230031, Anhui, China.

\section{Received: 2 January 2019 Accepted: 10 March 2019}

Published online: 14 March 2019

\section{References}

1. Brown KM, Arthur JR. Selenium, selenoproteins and human health: a review. Public Health Nutr. 2001:4:593-9.

2. Wang $S$, Nong $X$, Yang G. Selenium-rich diet induces myocardial structural and functional abnormalities by activating Caspase- 9 and Caspase- 3 in Gpx1P198L-overexpression transgenic mice. Med Sci Monit. 2019;25:61-70.

3. Tufarelli V, Laudadio V. Dietary supplementation with selenium and vitamin E improves milk yield, composition and rheological properties of dairy Jonica goats. J Dairy Res. 2011;78(2):144-8.

4. Tufarelli V, Ceci E, Laudadio V. 2-Hydroxy-4-methylselenobutanoic acid as new organic selenium dietary supplement to produce selenium-enriched eggs. Biol Trace Elem Res. 2016;171(2):453-8.

5. Lukaski HC. Selenium as a supplement. Annu Rev Nutr. 1999;19:279-302.

6. Jing CL, Dong XF, Wang ZM, Liu S, Tong JM. Comparative study of DL selenomethionine vs sodium selenite and seleno-yeast on antioxidant activity and selenium status in laying hens. Poult Sci. 2015;94:965-75.

7. Lin YC, Huang JT, Li MZ, Cheng CY, Lien TF. Effects of supplemental nanoparticle trivalent seleniumon the nutrient utilization, growth performance and serum traits of broilers. J Anim Physiol Anim Nutr (Berl). 2015;99:59-65

8. Brown KM. Pickard K, Nicol F, Beckett GJ, Duthie GG, Arthur JR, effects of organic and inorganic selenium supplementation on selenoenzyme activity in blood lymphocytes, granulocytes, platelets and erythrocytes. Clin Sci (Lond). 2000;98:593-9.

9. Karwacka A, Dullin P, Galbas M. The effects of selenium deficiency in animals. Postepy Biochem. 2014;60:365-70.

10. Hill C, Guarner F, Reid G, Gibson GR, Merenstein DJ, Pot B, Morelli L, Canani RB, Flint HJ, Salminen S, Calder PC, Sanders ME. Expert consensus document. The International Scientifc Association for Probiotics and Prebiotics consensus statement on the scope and appropriate use of the term probiotic. Nat Rev Gastroenterol Hepatol. 2014;11:506-14.

11. Park JH, Kim $\mathbb{H}$. The effects of the supplementation of Bacillus subtilis RX7 and B2A strains on the performance, blood profiles, intestinal Salmonella concentration, noxious gas emission, organ weight and breast meat quality of broiler challenged with Salmonella typhimurium. J Anim Physiol Anim Nutr (Berl). 2015;99:326-34

12. Liu X, Yan H, Lv L, Xu Q, Yin C, Zhang K, Wang P, Hu J. Growth performance and meat quality of broiler chickens supplemented with Bacillus licheniformis in drinking water. Asian Austral J Anim. 2012;25:682-9.

13. Bai K, Huang Q, Zhang J, He J, Zhang L, Wang T. Supplemental effects of probiotic Bacillus subtilis fmbJ on growth performance, antioxidant capacity, and meat quality of broiler chickens. Poult Sci. 2017;96:74-82.

14. Tufarelli V, Crovace AM, Rossi G, Laudadio V. Effect of a dietary probiotic blend on performance, blood characteristics, meat quality and faecal microbial shedding in growing-finishing pigs. S Afr J Anim Sci. 2017;47(6): 875-82.

15. Seidavi A, Dadashbeiki M, Alimohammadi-Saraei $M H$, van den Hoven $R$, Payan-Carreira R, Laudadio V, Tufarelli V. Effects of dietary inclusion level of a mixture of probiotic cultures and enzymes on broiler chickens immunity response. Environ Sci Pollut Res Int. 2017;24(5):4637-44

16. Urdaci MC, Lefevre M, Lafforgue G, Cartier C, Rodriguez B, Fioramonti J. Antidiarrheal action of Bacillus subtilis CU1 CNCM I-2745 and Lactobacillus plantarum CNCM I-4547 in mice. Front Microbiol. 2018;9:1537.

17. Deng W, Dong XF, Tong JM, Zhang Q. The probiotic Bacillus licheniformis ameliorates heat stress-induced impairment of egg production, gut morphology, and intestinal mucosal immunity in laying hens. Poult Sci. 2012;91:575-82.

18. Jahanian R, Rasouli E. Dietary selenium methionine supplementation could alleviate immuno suppressive effects of heat stress in broiler chicks. J Anim Sci. 2015;93:3355-63.

19. Yang JJ, Qian K, Wu D, Zhang W, Wu YJ, Xu YY. Effects of different proportions of two bacillus strains on the growth performance, small intestinal morphology, caecal microbiota and plasma biochemical profile of Chinese Huainan partridge shank chickens. J Integr Agr. 2017;16:1383-92.

20. National Research Council, Nutrient requirements of poultry. 11th rev. ed. Washington DC, USA: National Academy Press; 2012.

21. Wierbicki E, Deatherage FE. Determination of water-holding capacity of fresh meats. Agric Food Chem. 1958;6:387-92.

22. Pistón M, Silva J, Pérez-Zambra R, Dol I, Knochen M. Automated method for the determination of total arsenic and selenium in natural and drinking water by HG-AAS. Environ Geochem Health. 2012:34:273-8.

23. Kobayashi M, Sakai N, Kamijo K, Otani H, Hayashi M, Koike H, Baba I, Sasamoto T, Nemoto S, Shindo T, Takano I. Determination of Fluopicolide in livestock products and seafood by LC-MS/MS. Shokuhin Eiseigaku Zasshi. 2016:57:89-95.

24. Zhang ZF, Zhou TX, Ao X, Kim IH. Effects of $\beta$-glucan and Bacillus subtilis on growth performance, blood profiles, relative organ weight and meat quality in broilers fed maize soybean meal based diets. Livest Sci. 2012;150:419-24.

25. Bader J, Albin A, Stahl U. Spore-forming bacteria and their utilization as probiotics. Benef Microbes. 2012;3:67-75.

26. Jeong JS, Kim IH. Effect of Bacillus subtilis C-3102 spores as a probiotic feed supplement on growth performance, noxious gas emission, and intestinal microflora in broilers. Poult Sci. 2014;93:3097-103.

27. Yang J, Xu Y, Qian K, Zhang W, Wu D, Wang C. Effects of chromiumenriched Bacillus subtilis KT260179 supplementation on growth performance, caecal microbiology, tissue seleniumlevel, insulin receptor expression and plasma biochemical profile of mice under heat stress. $\mathrm{Br} J$ Nutr. 2016;15:774-81.

28. Han XJ, Qin P, Li WX, Ma QG, Ji C, Zhang JY, Zhao LH. Effect of sodium selenite and selenium yeast on performance, egg quality, antioxidant capacity, and selenium deposition of laying hens. Poult Sci. 2017;96:3973-80.

29. Li JL, Zhang L, Yang ZY, Zhang ZY, Jiang Y, Gao F, Zhou GH. Effects of different selenium sources on growth performance, antioxidant capacity 
and meat quality of local Chinese Subei chickens. Biol Trace Elem Res. 2018; 181:340-6.

30. Ohno A, Ano T, Shoda M. Effect of temperature on production of lipopeptide antibiotics, iturin a and surfactin by a dual producer, Bacillus subtilis RB14, in solid-state fermentation. J Ferment Bioeng. 1995;80:517-9.

31. Arthur JR. The glutathione peroxidases. Cell Mol Life Sci. 2000;57:1825-35.

32. McKenzie RC, Rafferty TS, Beckett GJ. Selenium: an essential element for immune function. Immunol Today. 1998;19:342-5.

33. Schrauzer GN. The nutritional significance, metabolism and toxicology of selenomethionine. Adv Food Nutr Res. 2003;47:73-112.

34. Lei XG. Glutathione peroxidase-1 gene knockout on body antioxidant defense in mice. Biofactors. 2001;14:93-9.

35. Mertz W. Selenium in human nutrition: a review. J Nutr. 1993;123:626-33.

36. Li JK, Wang XL. Effect of dietary organic versus inorganic selenium in laying hens on the productivity, selenium distribution in egg and selenium content in blood, liver and kidney. J Trace Elem Med Biol. 2004;18:65-8.

37. Yang JJ, Huang KH, Qin SY, Wu XS, Zhao ZP, Chen F. Antibacterial action of selenium-enriched probiotics against pathogenic Escherichia coli. Dig Dis Sci. 2009:54:246-54.

38. Yang J, Qian K, Zhang W, Xu Y, Wu Y. Effects of chromium-enriched bacillus subtilis KT260179 supplementation on chicken growth performance, plasma lipid parameters, tissue chromium levels, cecal bacterial composition and breast meat quality. Lipids Health Dis. 2016;15(1):188.

39. Zhou X, Wang Y, Gu Q, Li W. Effect of dietary probiotic, bacillus coagulans, on growth performance, chemical composition, and meat quality of Guangxi yellow chicken. Poult Sci. 2010;89:588-93.

40. Wen C, Jiang XY, Ding LR, Wang T, Zhou YM. Effects of dietary methionine on growth performance, meat quality and oxidative status of breast muscle in fast-and slow-growing broilers. Poult Sci. 2017;96:1707-14.

41. Arshad MS, Anjum FM, Asghar A, Khan MI, Yasin M, Shahid M, El-Ghorab AH. Lipid stability and antioxidant profile of microsomal fraction of broiler meat enriched with a-lipoic acid and a-tocopherol acetate. J Agric Food Chem. 2011;59:7346-52.

42. Chen H, Dong X, Yao Z, Xu B, Zhen S, Li C, Li X. Effects of prechilling parameters on water-holding capacity of chilled pork and optimization af prechilling parameters using response surface methodology. J Anim Sci. 2012:90:2836-41.

43. Rødbotten R, Nilsen BN, Hildrum Kl. Prediction of beef quality attributes from early post mortem near infrared reflectance spectra. Food Chem. 2000; 69:427-36.

44. Maltin CA, Warkup CC, Matthews KR, Grant CM, Porter AD, Delday MI. Pig muscle fibre characteristics as a source of variation in eating quality. Meat Sci. 1997:47:237-48.

45. Prescha A, Krzysik M, Zablocka-Slowinska K, Grajeta H. Effects of exposure to dietary selenium on tissue mineral contents in rats fed diets with fiber. Biol Trace Elem Res. 2014:159:325-31.

Ready to submit your research? Choose BMC and benefit from:

- fast, convenient online submission

- thorough peer review by experienced researchers in your field

- rapid publication on acceptance

- support for research data, including large and complex data types

- gold Open Access which fosters wider collaboration and increased citations

- maximum visibility for your research: over $100 \mathrm{M}$ website views per year

At $\mathrm{BMC}$, research is always in progress.

Learn more biomedcentral.com/submissions 